\title{
The Cause-Form-Effect Analysis of Conjugal Violence in Yoruba-Speaking States of Nigeria
}

\author{
Ayodele, Bimbo Rachel
}

Obafemi Awolowo University, Ile-Ife, Osun State

\section{Doi:10.5901/ajis.2014.v3n6p73}

\begin{abstract}
It has been established that wives accounted for more than $80 \%$ of all victims of conjugal violence and male aggression bears severe consequences. Therefore, this study made a cause-form-effect analysis of spousal violence in Yorubaland. It adopted a survey design. 142 wives were drawn by accidental random sampling from six Yoruba-speaking states of Nigeria (Ondo, Oyo, Osun, Ekiti, Ogun and Lagos). A self-structured, validated questionnaire was the data gathering tool. Data were analysed using simple percentage and results showed that family intrusion and infertility were ranked 1st and 2nd main factors of conjugal violence. Out of 142 respondents, 140 (98.6\%) and 103 (72.5\%) said that wives, mostly suffer psychological and economic effects of conjugal violence respectively and $98(69 \%)$ respondents said silence is adopted in situation of violence. Education, legislation and enforcement, researches, reporting and political and or economic empowerment of wives were suggested.
\end{abstract}

Keywords: spousal violence, Juju, widowhood and battering

\section{Introduction}

The thought of the home as a supportive springboard from where individuals could successfully face the outside world (Pearce, 1992) is often marred where violence among family members prevails. Sociologists have pointed to the fact that a happy family is built on the solid relationship existing between the husband and wife and that husband-wife relationship is the first factor in maintaining a happy home. Unfortunately, the conjugal lifestyles of many Nigerians do not portray happiness. This writer grew up in a polygamous home, where there was unthinkable chaos between the father and mothers, and each time, violence sprang from minute cause. The author also frequently witnessed warring situations in many other homes in the neighborhood, in which case, some ended in either separation or divorce, while several other homes remained intact with the wives suffering in silence. At that point, even as a young girl, several unanswered questions regarding whether or not violence is limited to polygamous homes, forms, etiology and effects of violence and help seeking during violence bothered the researcher's mind. An attempt to answer these and many other questions relating to abuse of womanhood prompted this research.

Spousal Violence (SV), Intimate Partner Violence (IPV) or Conjugal Violence (CV) as defined by Stefanakis (2004) is the physical, sexual, psychological and financial abuse within the current or former marital or common law relationships regardless of sexual orientation. Such sexual orientations include marriage, dating, family or cohabitation. In the Japanese law, SV is used to connote illegal attacks from one spouse (including persons who are in a de facto state of marriage, even if it has not been legally registered) that threaten the spouse's life or physical condition. From these definitions, either the husband or the wife could act either the abused or abuser's role, but within the context of this research, the focus is on husbands' violence against their wives. This delimitation is justified because, it has been established that wives are most often the victims of CV (WHO, 2002; Bryant, 2006; Johnson, 2007; Obi \& Ozumba, 2007 and Alokan (2013) and that the after-effects of male aggression are more severe, injury-causing (Stefanakis, 2004) and more often repeated than female aggression (Canadian Dept. of Justice, 2004).

The widespread of SV worldwide had been confirmed. Globally, WHO cited by Koustuv (2008) and Yusuf, et. al. (2011) revealed that in 48 population-based surveys around the world, between 10-69 women are victims of domestic violence while UNFPA (2002) reported 60\% abused women worldwide. In India, the NFHS-3 revealed that nearly two in every five married women have experienced some form of violence by husbands. In USA, women experienced about 4.8million intimate partner-related physical assaults and rape and even in Ghana, SV tops the list of domestic violence. In Nigeria, despite the fact that CV especially among the elites is underreported (Moronkola, 2003; Adewale, 2009; Ashimolowo \& Otufale, 2012; Adebayo \& Kolawole, 2013; Adebayo, 2013) for fear of divorce, abuser's retaliation, stigmatization and loss of economic support, yet, the situation is not different. Pearce (1992) specifically found that in lle- 
Ife (the homeland of the Yorubas), wife assault is not only common, but highly visible. In line with this, Etuk, Nwagbara and Achibong (2012) found that of the 504 respondents in their study in Niger Delta State of Nigeria, 344 (68.2\%) had been exposed to a form of CV while only $44(8.8 \%)$ have not. Adebayo (2013) revealed that about $50 \%$ or two thirds of Nigerian women are subjected to SV, while Alo, Odusina \& Babatunde (2012) estimated CV prevalence rate in the SouthWest of Nigeria to be $32 \%$. Same were reported by Project Alert (2007) and AfrolNews (2007). However, Ashimolowo \& Otufale (2012) had contrary findings as they revealed that majority of their respondents in Ogun State of Nigeria never experienced domestic violence.

$\mathrm{CV}$ takes various forms and dimensions in different settings. These forms which were categorized as physical, emotional, sexual and sustenance/economic (Koustuv, 2008) ranged from mild abuse such as ear-pulling to irreversible cases of brutal killing. The nature and elements in these forms of violence is presented as Figure 1.

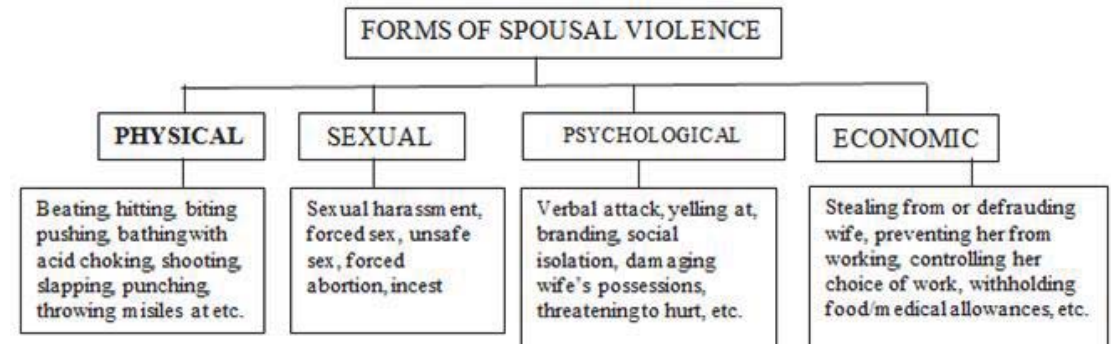

Figure 1: Forms of Violence (Koustuv, 2008)

On comparative basis, Koustuv (2008) found that $79 \%$ of his respondents were exposed to verbal abuse while $41 \%$ were physically abused and only 5\% have faced sustainance/financial abuse. In line with these findings, Etuk, et.al. (2012) found that $68 . \%$ of his respondents were exposed to psychological violence, while only (2.7\%) suffered economic violence. According to Alo, et.al. (2012), the common forms of physical violence were kicking, pushing, slapping, arm twisting or throwing things at and forced intercourse was the commonest sexual violence.

According to the Canadian Department of Justice (2004), there is no single, definitive cause of CV. Moronkola (2003), Stefanakis (2004) and Kaufman (2005) linked CV to societal inequalities and power imbalances. In support, Musa (2008) attributed gender violence to the sexual class system, an earlier form of stratification, arguing that men and women were created different and not equally privileged. Supporting this phenomenon, Ndegbe cited by Ashimolowo and Otufale (2012) said that in rural Nigeria, women exploitation is perpetrated where the relationship between men and women is that of senior-junior.

Basically, WHO (2002) identified poverty as the most profound background of violence against both children and women. The higher the socio-economic status of the family, the lower the incidence of domestic violence (Olujide, et. al. 2011). The ecological model of risk factors of violence was explained at 4 main levels, i.e. individual, relationship (family), community and societal levels. These risk factors cited by Koustuv (2008) are shown in figure 2.

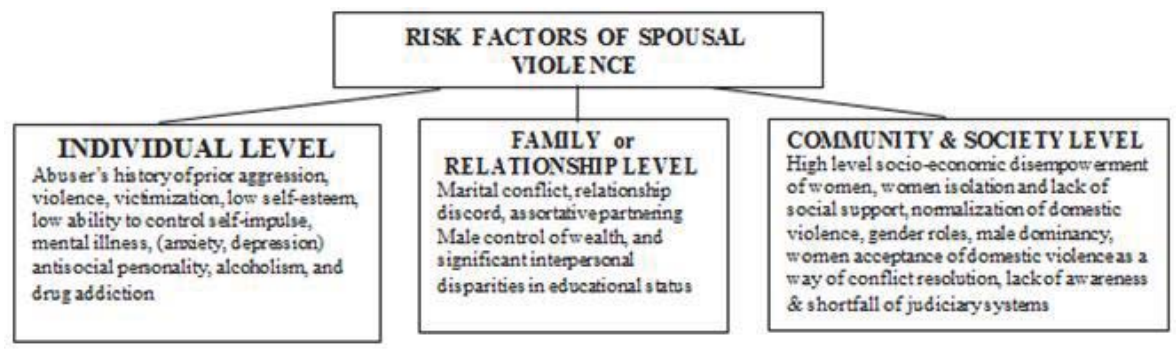

Fig. 2: Factors in Spousal Violence (Totlan, et.al. 2008 and UNO, 2006 cited by Koustuv, 2008)

Other related risk factors of CV include: wide age difference between husband and wife, wife's age at first marriage (Alo, et.al 2012), religion, illiteracy, husband's occupation, dowry, husband monetary greed, and husband's extramarital affair (Koustuv 2008), argument about money, sexual jealousy, sexual refusal and stress which often arises from economic and social problems (Lawrence, 1984). Alo, et.al. (2012) also found relationship between CV and women employment status, 
number of children, cohabitation, husband's consumption of alcohol and violent background. Specifically, Aihie (2011) in his review found that $56 \%$ of Indian women justified wife-beating on grounds of bad cooking, disrespect to in-laws and producing girls among others. The role of widow inheritance (Musa, 2008) and family intrusion (Pearce, 1992) in the etiology of conjugal violence in Nigeria is worth nothing. Whatever pattern CV takes e.g Common Couple Violence (CCV), Intimate Terrorism (IT), Violence Resistance (VR) and Mutual Violent Control (MVC) patterns (Johnson, 1993), the consequences are often not palatable.

CV affects virtually every aspect of an abused person's life. The Canadian center for Justice (2004) said that it can harm their physical and mental health, ability to work, and relationship with their children and loved ones and being abused can destroy a person's sense of efficacy and self worth. Physically, Koustuv (2008) in his review, found that CV may result in bruises and even fractures, while the Canadian Center for Justice (2000) reported that in some cases, killing result. The report also showed that in 1999, more than 500 women and 100 men were either killed or seriously injured by their partners. These reports were confirmed by Musa (2008), Alokan (2013) and Adebayo (2013). The World Development report reviewed by Olujide, Oluremi and Adeusi (2011) indicated that SV is as serious a cause of death and incapacity among women of reproductive age as cancer and a greater cause of ill-health than traffic accidents and malaria combined.

Psychologically, SV victims reported depression, anger, drug and alcohol abuse, guilt, lowered self-esteem, intimidation and emotionally destructive environment. Emenike, Lawoko and Dalal (2008) stated that the victims exhibit higher health risk behaviours such as unhealthy feeding habits, substance abuse, alcoholism and suicidal behaviours when compared to non-abused women. In his review, Koustuv (2008) said that abused women encounter miscarriages, pre-term labour, foetal injury/death abortion, undesired pregnancy, child loss during infancy to a higher degree than their peers in non-violent intimate relationship (Jones 1997). Musa (2008) added that fracture, frequent falls, home or car accidents, enuresis, contraction of diseases like HIV AIDS were after-effects of SV. The authors opined that SV has both direct and indirect devastating effect on children. They submitted that there is the possibility of infant dropping or accidental injury, abduction of children by abusing spouse, denial of access to children, etc. Mia and Johnson (2003) said that children who are exposed to violence in their homes may experience developmental, behavioural and academic difficulties. Economically, the cost of CV is enormous when such indexes as damaged health, wage loss and social instability are estimated. Such costs could be direct (monetary) or indirect (non-monetary). Abama and Kwaja (2009) stressed that violence is a major obstacle to growth and development and that it hinders progress in achieving development targets in Nigeria.

Despite the grave effects, domestic quarrel is widely condoned in many African countries including Nigeria. The Penal Code Law Cap 89 Laws of Northern Nigeria did not consider SV an offence if committed by a husband for the purpose of correcting his wife. To worsen the situation, strategies to cope with SV as revealed in the study of Ashimolowo and Otufale (2012) was for the abused to remain silent and rarely do they seek social support. The reports showed that as many as $75.9 \%$ and $71.80 \%$ abused wives neither reported to the police nor sought counsel in religious homes respectively. This result corroborated those of Olujide, et. al. (2011) where only $11 \%$ and $5 \%$ of abused wives said that they reported the crime to religious leaders and police respectively. No wonder why many wives in Nigeria and especially the Yoruba speaking States are still relegated to the status of children in their homes despite current efforts to view CV as a criminal offence. Major of the problem is the fact that cases are underreported, reliable prevalence statistics are not available and most academic researches on SV are non-empirical. The need to carry out an empirical cause-form-effect analysis to provide a clearer picture of the problem in Yoruba-land and direct efforts towards eradicating, or in the least provide adequate relieve or help to the victims form the backdrop for this research. The following objectives were generated.

1. To make cause-form effect analysis of spousal violence in Yoruba land and

2. examine how abused wives sought help.

\section{Methodology}

This study adopted the survey design. It analysed the responses of a total of 142 wives on questions on conjugal violence. Both stratified and accidental sampling techniques were used to draw respondents from six Yoruba- speaking States of Nigeria (Ondo, Oyo, Osun, Ogun, Ekiti and Lagos). Yoruba is one of the four major tribes in Nigeria and it is in the Western part of the country. Twenty three respondents were sampled from each of the first five States, while 27 respondents were drawn from Lagos State. A self-constructed validated questionnaire was the data gathering tool. Data were analysed using simple percentage. The results are presented as follows: 


\section{Results}

Data gathered on the respondents' background indicated that out of 142 respondents, 110 (77.4\%) were married while 18 (12.7\%) were divorced. Widows constituted 10 (9.9\%), while the remaining 4 (4\%) were in cohabitation relationship.

Table 1: Percentile Distribution of Responses on the Occurrence of Physical Violence Against Wives

\begin{tabular}{|l|c|c|c|c|}
\hline Physical Violence & Often No (\%) & Seldomly No (\%) & Never occurred No (\%) & Total No (\%) \\
\hline a. Slapping & $80(53.3)$ & $55(38.7)$ & $7(4.9)$ & $142(100)$ \\
b. Battering/beating (no injury) & $96(67.6)$ & $44(30.99)$ & $2(1.4)$ & $142(100)$ \\
c. Battering (with injury/coma) & $12(8.5)$ & $36(25.4)$ & $9(66.2)$ & $142(100)$ \\
d. Acid bath & $0(0.00)$ & $18(12.7)$ & $124(87.3)$ & $142(100)$ \\
e. Matcheting/cutting & $2(1.4)$ & $20(14.1)$ & $120(84.6)$ & $142(100)$ \\
f. Stoning/throwing objects at & $0(0.00)$ & $36(25.4)$ & $106(74.6)$ & $142(100)$ \\
g. Shooting & $0(0.00)$ & $0(0.00)$ & $142(100)$ & $142(100)$ \\
\hline
\end{tabular}

Data in table 1 indicated that out of 142 respondents, 96 (67.6\%) and 80 (56.3\%) said that wife battering (no injury) and slapping respectively were physical violent acts often suffered from husbands. Over $70 \%$ respondents claimed that stoning, matchetting and acid bath by husbands never occurred in their neighborhood, a 100\% respondents said that shooting of wives never occurred.

Table 2: Percentile Distribution of Responses on the Occurrence of Sexual Violence Against Wives

\begin{tabular}{|l|c|c|c|c|}
\hline Sexual Violence & $\begin{array}{c}\text { Often } \\
\text { No (\%) }\end{array}$ & $\begin{array}{c}\text { Seldomly } \\
\text { No (\%) }\end{array}$ & $\begin{array}{c}\text { Never } \\
\text { Occurred No (\%) }\end{array}$ & $\begin{array}{c}\text { Total } \\
\text { No (\%) }\end{array}$ \\
\hline a. $\quad$ Denying wife of sex & $52(36.6)$ & $50(35.2)$ & $40(28.2)$ & $142(100)$ \\
b. $\quad$ Forcing wife to bear more children & $50(35.2)$ & $67(47.2)$ & $25(17.6)$ & $142(100)$ \\
c. $\quad$ Husband raping wife & $4(2.8)$ & $22(15.5)$ & $116(61.7)$ & $142(100)$ \\
d. $\quad$ Trading wife to get favour from another man. (job, money) & $12(8.5)$ & $22(15.5)$ & $108(76.1)$ & $142(100)$ \\
e. $\quad$ Brutalizing wife before sex & $0(0.00)$ & $0(0.00)$ & $142(100)$ & $142(100)$ \\
f. $\quad$ Calling wife false name & $99(69.7)$ & $36(25.4)$ & $7(4.9)$ & $142(100)$ \\
g. $\quad$ Trading wife for rituals & $59(41.6)$ & $20(14.1)$ & $63(44.4)$ & $142(100)$ \\
h. $\quad$ Forcing wife to be circumcised & $0(0.00)$ & $0(0.00)$ & $142(100)$ & $142(100)$ \\
i. $\quad$ Forcing wife into sex when drunk & $101(71.1)$ & $37(26.1)$ & $4(2.8)$ & $142(100)$ \\
j. $\quad$ Forcing wife to abort pregnancy & $10(7.0)$ & $21(14.8)$ & $111(72.8)$ & $142(100)$ \\
k. $\quad$ Neglecting wife during pregnancy & $42(29.6)$ & $39(27.5)$ & $61(43)$ & $142(100)$ \\
\hline
\end{tabular}

Out of 142, as many as 99 (69.7\%) respondents said that wives in their neighborhood are often branded or called false names by husbands as against only 36 (25.5) and 7 (4.9) respondents who said that husbands branding wives was not frequent and never occurred respectively. However, $142(100 \%)$ respondents said that brutalizing or beating wives before sex or forcing wife to be circumcised never occurred in their neighbourhood.

Table 3: Percentile Distribution of Responses on the Occurrence of Psychological Violence Against Wives

\begin{tabular}{|l|c|c|c|c|}
\hline Forms of Psychological Violence & $\begin{array}{c}\text { Often } \\
\text { No (\%) }\end{array}$ & $\begin{array}{c}\text { Seldomly } \\
\text { No (\%) }\end{array}$ & $\begin{array}{c}\text { Never occurred } \\
\text { No (\%) }\end{array}$ & $\begin{array}{c}\text { Total } \\
\text { No (\%) }\end{array}$ \\
\hline a. Husband abandoning meals & $103(72.5)$ & $31(21.8)$ & $8(5.6)$ & $142(100)$ \\
b. Husband abandoning home & $96(67.6)$ & $31(21.8)$ & $15(10.6)$ & $142(100)$ \\
c. Extramarital affairs & $56(39.4)$ & $60(42.3)$ & $26(18.3)$ & $142(100)$ \\
d. Constant nagging & $120(84.5)$ & $22(15.5)$ & $0(0.00)$ & $142(100)$ \\
e. Impregnating wards & $112(78.8)$ & $10(7.0)$ & $20(14.1)$ & $142(100)$ \\
f. Ordering wife out of house especially at night & $24(16.9)$ & $100(70.4)$ & $18(12.7)$ & $142(100)$ \\
g. Abusing/ cursing wife verbally & $100(70.4)$. & $26(18.3)$ & $16(11.3)$ & $142(100)$ \\
h. Threatening wife with juju/gun & $66(46.5)$ & $66(46.5)$ & $10(7.0)$ & $142(100)$ \\
i. Intrusion of husband's relations & $109(76.8)$ & $30(21.1)$ & $3(2.1)$ & $142(100)$ \\
j. Confinement of wives & $3(2.1)$ & $15(10.6)$ & $124(87.3)$ & $142(100)$ \\
\hline
\end{tabular}

In table 3, data showed that constant nagging of wives (84.5\%); husband having sex/impregnating wards (78.8\%); husband's family intrusion (76.8\%); husbands abandoning meals (72.5\%); abusing wife verbally (70.4\%) and husbands 
abandoning homes (67.6\%), were psychological violence frequently suffered by wives. Also, 100 (70.4\%) respondents indicated that ordering wives out of the house especially at night seldomly occurred in their neighbourhood as against 18 $(12.7 \%)$ who said that it never occurred.

Table 4: Percentile Distribution of Responses on the Occurrence of Economic Violence Against Wives

\begin{tabular}{|l|c|c|c|c|}
\hline Forms of Economic Violence & $\begin{array}{c}\text { Often } \\
\text { No (\%) }\end{array}$ & $\begin{array}{c}\text { Seldomly } \\
\text { No (\%) }\end{array}$ & $\begin{array}{c}\text { Never occurred } \\
\text { No (\%) }\end{array}$ & $\begin{array}{c}\text { Total } \\
\text { No (\%) }\end{array}$ \\
\hline a. Husband abandoning financial responsibilities to the wife & $141(99.3)$ & $1(0.0 .7)$ & $0(0.00)$ & $142(100)$ \\
b. Stealing wife's money & $51(35.9)$ & $36(25.4)$ & $55(38.7)$ & $142(100)$ \\
c. Denying wife of engaging in a particular trade/ occupation & $100(70.4)$ & $10(7.0)$ & $32(22.5)$ & $142(100)$ \\
d. Squandering wives resources & $40(28.2)$ & $20(14.1)$ & $82(57.7)$ & $142(100)$ \\
e. Denying wife access to joint account & $0(0.0)$ & $1(0.7)$ & $141(99.3 \%)$ & $142(100)$ \\
\hline
\end{tabular}

In table 4, data revealed that husbands often abandon their responsibilities at home and deny their wives of engaging in a particular trade/occupation as revealed by 141 (99.3\%) and 100 (70.4\%) respondents respectively. Majority; 141 (99.3\%) respondents said that denying wives access to joint account never occurred as against only $1(0.7 \%)$ respondent who said it seldomly occurred.

Table 5: Percentile Distribution of Responses on the Occurrence of Widowhood-related Violence Against Wives

\begin{tabular}{|l|c|c|c|c|}
\hline Forms of Widowhood - Related Violence & $\begin{array}{c}\text { Often } \\
\text { No (\%) }\end{array}$ & $\begin{array}{c}\text { Seldomly } \\
\text { No (\%) }\end{array}$ & $\begin{array}{c}\text { Never Occurred } \\
\text { No (\%) }\end{array}$ & $\begin{array}{c}\text { Total } \\
\text { No (\%) }\end{array}$ \\
\hline a. Forcing widow to marry the relation of her late husband & $60(42.3)$ & $60(42.3)$ & $22(15.5)$ & $142(100)$ \\
b. Confisticating late husband's properties & $60(42.3)$ & $60(42.3)$ & $22(15.5)$ & $142(100)$ \\
c. Forcing widow to sleep with her husband's corpse & $0(0.00)$ & $0(0.00)$ & $142(100)$ & $142(100)$ \\
d. Branding widow a witch & $116(81.7)$ & $14(9.9)$ & $12(8.5)$ & $142(100)$ \\
e. Forcing widow to swear & $116(81.7)$ & $14(9.9)$ & $12(8.5)$ & $142(100)$ \\
f. Forcing widow out of her husband's house & $58(40.8)$ & $26(18.3)$ & $58(40.8)$ & $142(100)$ \\
g. Debarring widow from re-marrying & $2(1.4)$ & $19(13.4)$ & $121(85.2)$ & $141(100)$ \\
\hline
\end{tabular}

Data in table 5 indicated that branding as witch and forceful swearing are forms of violence often suffered by widows as attested to by $116(81.7 \%)$ respondents, while only $12(8.5 \%)$ respondents said that such forms of violence never occurred in their neighbourhood. All the $142(100 \%)$ respondents said that forcing widow to sleep with her husband's corpse never occurred in their neighborhood.

Table 6: Specific Causes of Conjugal Violence

\begin{tabular}{|l|c|c|c|}
\hline Specific causes of conjugal violence & Accountability score & $\%$ & Rank \\
\hline a. Barrenness & 1,040 & 91.5 & $2^{\text {nd }}$ \\
b. Failure to have preferred sex of child & 510 & 44.9 & $5^{\text {th }}$ \\
c. Economic factors (poverty) & 367 & 32.3 & $6^{\text {th }}$ \\
d. Differences in background (religion, cultural, academic etc.) & 367 & 32.3 & $6^{\text {th }}$ \\
e. Family intrusion & 1,136 & 100 & $1^{\text {st }}$ \\
f. Wives' refusal to be dominated & 999 & 87.9 & $3^{\text {rd }}$ \\
g. Sex issues & 645 & 56.8 & $4^{\text {th }}$ \\
h. Unequal gender power (exploitation) & 198 & 17.4 & $7^{\text {th }}$ \\
\hline
\end{tabular}

Data in table 6 indicated that family intrusion and bareness with accountability scores of 1,136 and 1,040 were ranked 1st and 2nd causal factors in conjugal violence in Yoruba land whereas, unequal gender power between husbands and wives with accountability score of 198 was ranked least among the causes of conjugal violence. 
Table 7: Percentile Distribution of Responses on the Effects of Conjugal Violence

\begin{tabular}{|c|c|c|c|}
\hline Effects of Conjugal Violence & $\begin{array}{c}\text { Yes } \\
\text { No (\%) }\end{array}$ & $\begin{array}{c}\text { No } \\
\text { No (\%) }\end{array}$ & $\begin{array}{c}\text { Total } \\
\text { No }(\%)\end{array}$ \\
\hline a. Physical effects (e.g bruises, fracture, bleeding, burns, death, etc.) & $59(41.5)$ & $83(58,5)$ & $142(100)$ \\
\hline b. Social effects (anti-social behaviours- solo parenting, alcoholism, drug use etc.) & $26(18.3)$ & $116(81.7)$ & $142(100)$ \\
\hline $\begin{array}{l}\text { c. Psychological effects (e.g. stress, depression, guilt, nightmares, trauma, confusion, } \\
\text { isolation, low self esteem etc.) }\end{array}$ & $140(98.6)$ & $2(1.4)$ & $142(100)$ \\
\hline d. Economic effects (e.g. poverty) & $103(72.5)$ & $39(27.5)$ & $142(100)$ \\
\hline e. Effect on child (academics, health etc.) & $96(67.6)$ & $46(32.4)$ & $142(100)$ \\
\hline
\end{tabular}

Data in table 7 depicted that majority: 140 (98.6\%) and 103 (72.5\%) respondents said that wives mostly suffer psychological and economic effects of SV respectively, whereas only 2 (1.4\%) and $39(27.5 \%)$ had contrary views respectively. Physical effects were not suffered by wives as indicated by $83(58.5 \%)$ of the respondents, while 59 (41.5\%) had contrary submissions. Additionally, as many as $96(67.6 \%)$ respondents attested to the effects of SV on children as against 46 (32.4\%) respondents who said that it does not have effect on children.

Table 8: Percentile Distribution of Responses on Help Seeking Measures During Conjugal Violence

\begin{tabular}{|l|c|c|c|}
\hline Sources of Help & Yes No (\%) & No No (\%) & Total No (\%) \\
\hline a. Police station & $14(9.9)$ & $128(90.1)$ & $142(100)$ \\
b. Welfare office & $2(1.4)$ & $140(98.6)$ & $142(100)$ \\
c. Families and friends & $82(57.7)$ & $60(42.3)$ & $142(100)$ \\
d. Don't seek help (keep silent) & $44(31)$ & $98(69)$ & $142(100)$ \\
e. Religious homes & & & \\
\hline
\end{tabular}

Data in table 8 showed that $82(57.7 \%)$ out of 142 respondents said that abused wives in their neighborhoods sought help from their family members or those of their husbands, while 60 (42.3) had contrary view. Also, 44 (31\%) respondents said that abused wives in their neighborhoods did not seek help.

\section{Discussion of Findings}

The results of this study, which indicated that wife beating and slapping often occurred among couples in the Yoruba speaking States of Nigeria was in line with the earlier findings of Pearce (1992), and Alo, et. al. (2012), but ran contrary to those of Koustuv (2008), Canadian Center for Justice (2000) and World Development Report cited by Olujide, et. al. (2011) that women are killed by their violent husbands, because, the current result indicated that shooting, stoning and matchetting that could result in death of wives never occurred in their neighbourhoods. The disparity in these results could be accounted for, by the differences in culture and orientation of the respondents in the two studies. Unlike their foreign counterparts, most Nigerian men do not handle guns except they are hunters or during civil strife. There is also the tendency to withhold information relating to spousal violence that resulted in death,

Branding or false name-calling often experienced by wives in this study was earlier found by Pearce (1992). The fact that this study revealed that husbands brutalizing wife before sex never occurred in the respondents' neighbourhood is an indication that sadism as a sexual deviance is not popular among Nigerian men. Both the current study and that of Pearce (1992) agreed that family intrusion is a main risk factor in CV, but contradicted WHO (2002), Olujide (2011) and Etuk, et. al. (2012) that CV is caused by poverty. Also, the results of this study tallied with those of Emenike, et. al. (2008) that abused women suffered psychological effects, but ran contrary to Koeing, et. al. cited by Koustuv (2008) that assaulted women sustain injuries which ranged from bruises to fractured bones. It is evident in this study that the differences in the two results could be due to the fact that battered wives who sustained injuries might not have disclosed to others, the true cause of their injuries where they are visible. The results of this study contradicted the submission of the Canadian Department of Justice that many abused women never talked about their abuse or seek help from the police, but was in line with NFHS-3 reports that abused women often seek help from families.

\section{Conclusions and Recommendations}

Based on the results of this study, it was concluded that since CV is underreported and wives do not seek help from 
appropriate quarters except from families, there may be increased prevalence and more grave effects are likely to be suffered by wives in abusive homes. On the basis of these conclusions, the following recommendations were made:

(a) Formal and informal education: Family life education should be included in the school curriculum at all levels. This may go a long way to affect changes in the cultural orientation of Nigerians which places women in a subordinate status. From health education teaching either in schools or in the community, men and boys could learn much about healthy male-female relationship.

(b) Legislation and enforcement: Government policies which protect women and girls against violence should be established and well enforced.

(c) Reporting: Abused wives should be encouraged to report cases to appropriate units e.g. police station and welfare units that could render adequate helps. This could be accomplished through community-based fora.

(d) Researches: More academic surveys on gender and violence should be carried out using other Nigerian tribes.

(e) Political and economic empowerment of women to bridge the existing wide gap between male - female status was also suggested.

\section{References}

Abama, E. and Kwaja, C.M.A. (2009). Violence against women in Nigeria: How the millennium development goals address the challenge. The Journal of Pan African Studies. 3 (3) 23 - 34

Adebayo, A.A. (2013). Sociological implications of domestic violence on children's development in Nigeria. Journal of African Studies and Development. 6 (1) 8 - 13

Adebayo, A.A., and Kolawole, T.O. (2013). Domestic violence and death: Women as endangered gender in Nigeria. American Journal of Sociological Research. 3 (3) $53-60$

Adewale, R. (2007). Violence in the family: A preliminary investigation and overview of wife battering in Africa. Journal of International Women' Studies. 9 (1) $234-251$

AfroNews (2007). Half of Nigeria's women experience domestic violence. Retrieved 22nd of May, 2008 from http://.afro.com/ articles/16471.

Aihie, O.N. (2009). Prevalence of domestic violence in Nigeria: Implications for Counselling. Edo Journal of Counselling.2 (1) 1 - 8

Alo, O.A., Odusina, E.K., Babatunde, G. (2012). Spousal violence in South-West, Nigeria: Prevalence and correlates. Journal of Womens' Health Care. 1 (2) 110

Alokan, F.B. (2013). Domestic violence against women: A family menace. Proceedings of the 1st Annual International Interdisciplinary Conference. Held 24th - 26th of April, 2013. Azores Portugal. Pp. 100 - 105

Ashimolowo, O.R. and Otufale, G.A. (2012). Assessment of domestic violence among women in Ogun State, Nigeria. Greener Journal of Social Sciences. 2 (3) 102 - 114

Canadian Department of Justice (2004). Spousal abuse. A fact sheet. 1 - 5

Canadian Department of Justice (1993). The violence against women survey (VAWS). Ist Population survey. 1 - 10

Etuk, G.R., Nwagbara, E.N. and Archibong, E.P. (2012). Working women and spousal violence in Nigeria: Emerging patterns and strategies for change. International Journal of Business and Social Science. 3 (17) 272 - 277

Johnson, H. (1996). Dangerous domains: Violence against women in Canada. Nelson, Canada. Scarborough, O. N.

Johnson, M.P. (1995). Patriarchal terrorism and common couple violence: Two forms of violence against women. Journal of Marriage and Family. 57 (2) $283-294$

Jones, R.H. (1997). The American College of Obstetricians and Gynaecologists: A decade of responding to violence against women. International Journal of Gynaecology and Obstetrics 58 (1) 43 - 50

Koustuv, D. (2008). Causes and consequencies of child labour and women in developing countries. Stockholm, Karolinaka Institute. Pp. $1-25$

Mia, D. and Johnson, H. (2003). Children witnessing family violence. Juristat. 21 (6)

Moronkola, O.A. (2003). Essays on issues in health. Ibadan, Nigeria. Royal People Ltd. Pp. 52-55

Musa, C.N. (2008). Gender violence in Nigeria:A review. Benin Journal of Gender Studies 1 (1) 85-96

Nicholas, M.C., Lorne, D.B., Joanne, J.P., Bartha, M.K., Joseph, P.H., Jean Francois, N. Locraine, B. and Susan, W.M. (1998). Spousal violence in custody and access disputes. Recommendation Reforms.http://www.swc.cfs.gc.ca/ Retrieved June, 2013

Obi, S.N., Ozumba, B.C. (2007). Factors associated with domestic violence in South East, Nigeria. Journal of Obstetrics and Gynaecology 27 (1) $75-78$

Olujide, A.A., Oluremi, H.A., Sussan, O.A. (2011). Domestic violence in a semi-urban neighbourhood. Gender and Behaviour. 9 (2) 4247 $-4261$

Pearce, T.O. (1992). Assaulting a wife: Perspectives of conjugal violence. In Women Health Issues in Nigeria. Mere, N.k. (Ed.). Zaria, Nigeria, Tamaza Publishing Company. Ltd. Pp. 191-199

Stefanakis, P. (2004). Desistence from violence understanding. How men negotiate.

UNFPA (2002). World report on violence and health. Geneva. 
World Health Organisation (2002). Intimate partner violence. Retrieved from http://www.who.int/violence_injury_prevention/violence/ world report/factsheets

Yusuf, O.B., Arulogun, O.S., Oladepo, O., Olowookere, F. (2011). Physical violence among intimate partners in Nigeria: A multi level analysis. Journal of Public Health Epidemiology. 3 (5) 240 - 245 